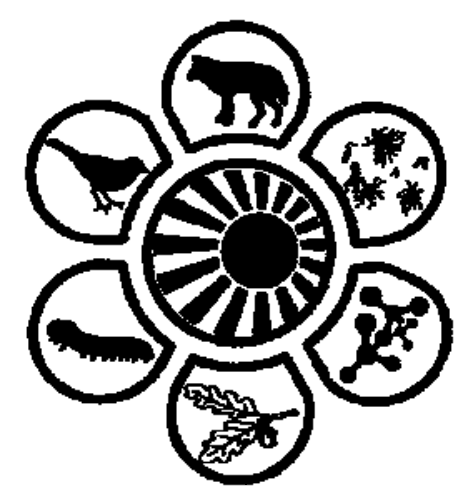

Вісник Дніпропетровського університету. Біологія, екологія.

Vìsnik Dnìpropetrovs'kogo unìversitetu. Seriâ Bìologiâ, ekologiâ

Visnyk of Dnipropetrovsk University. Biology, ecology.

Vìsn. Dnìpropetr. Unìv. Ser. Bìol. Ekol. 2015. 23(2), 112-115.

doi: $10.15421 / 011516$

ISSN 2310-0842 print

ISSN 2312-301X online

www.ecology.dp.ua

УДК 595.422:630

\title{
Екологія та поширення Euseius finlandicus (Parasitiformes, Phytoseiidae) у садах Закарпатської області
}

\author{
К.В. Штимак \\ Ужггородський національний університет, Ужгород, Украйна
}

Описано екологію та поширення Euseius finlandicus Oudemans, 1915 (Parasitiformes, Phytoseiidae) у садових фітоценозах Закарпатської області. В Україні подібні дослідження проведено для зони Лісостепу. Кліщів збирали протягом 2012-2014 рр. Досліджено 9 населених пунктів Закарпатської області. На території досліджень Eu. finlandicus заселяє щонайменше 26 видів рослин. Уперше визначено статус виду в акарокомплексах родини Phytoseiidae у садових фітоценозах Закарпатської області. Для виду розраховано індекси трапляння та домінування. Описано види рослин, на яких трапляється Eu. finlandicus у вказаних фітоценозах. Результати дозволяють вважати Eu. finlandicus фоновим видом у садових фітоценозах Закарпатської області. Отримані результати можуть стати теоретичною основою для розроблення схем підвищення захисної функції корисних кліщів у фітоценозах Ужгородського району.

Ключові слова: фітосеїдні кліщі; індекс трапляння; індекс домінування

\section{Ecology and distribution of of Euseius finlandicus (Parasitiformes, Phytoseiidae) in garden phytocenoses of Transcarpathian region}

\author{
K.V. Shtymak \\ Uzhgorod National University, Uzhgorod, Ukraine
}

The article describes the ecology and distribution of the species Eu. finlandicus Oudemans, 1915 (Parasitiformes, Phytoseiidae) in the garden phytocenoses of Transcarpathian region. In Ukraine, such studies were conducted for the Forest-Steppe zone. The mites were collected during the period of 2012-2014. In total, nine settlements of Transcarpathian region were studied. On the researched territory $E u$. finlandicus inhabits at least 26 species of plants. For the first time, the status of the species Eu. finlandicus is determined in acarocomplexes of the family Phytoseiidae in garden phytocenoses of Transcarpathian region. The indices of occurrence and dominance for this species are calculated. Species of plants on which Eu. finlandicus is present in garden phytocenoses of Transcarpathian region are described. Results of the study suggest that Eu. finlandicus is a common species in garden phytocenoses of Transcarpathian region. The results can become the theoretical basis for development of schemes aimed at enhancing the protective function of useful mites in phytocenoses of the Uzhgorod district.

Keywords: phytoseid mites; index of occurrence; index of dominance

Ужсгородський наиіональний університет, вул. Волошина, 32, Ужсгород, 88000, Украӥна

Uzhgorod National University, Voloshyn Str., 32, Uzhgorod, 88000, Ukraine

Tel.: +38-066-758-80-62.E-mail: k.shtymak@meta.ua 


\section{Вступ}

Садові фітоценози - невід'ємна частина ландшафтів Закарпатської області. Важливий біотичний фактор, що впливає на довговічність рослин, - це комплекси кліщів, серед яких ключову роль відіграють хижі кліщіфітосеїди (Parasitiformes, Mesostigmata, Phytoseiidae). Саме ці кліщі є природними регуляторами чисельності різних груп членистоногих. Тому різноманіття фітосеїдних кліщів визначає ступінь захищеності рослин від різноманітних шкідників. Хижі кліщі-фітосеїди можуть контролювати розвиток локальних спалахів завезених шкідників-фітофагів (Kolodochka and Omeri, 2011). Оскільки у Закарпатській області добре розвинене садівництво, дослідження комплексів хижих-кліщів фітосеїд актуальне. Мета нашого дослідження полягала у виявленні домінантного виду у комплексах кліщівфітосеїд садових фітоценозів Закарпатської області. Аналогічні дослідження проведені для садово-паркових фітоценозів Лісостепу України (Omeri, 2013).

Низка праць присвячена вивченню видового складу кліщів-фітосеїд України, які заселяють рослини дендрологічних парків і ботанічних садів на території Центрального Лісостепу (Kolodochka, 2006; Akimov, 2007; Omeri, 2008, 2013). Найповніше дослідженнями охоплено урбоекосистеми Київської області (Kolodochka, 2007; Hrabovska, 2014). Окрема праця присвячена вивченню видового складу кліщів родини Phytoseiidae на території Східних Карпат, де виявлено 35 видів 9 родів (Kolodochka, 1993). На вказаних вище територіях домінує саме Eu. finlandicus.

\section{Матеріал і методи досліджень}

За характером рельєфу Закарпаття - гірська область. Гори та передгір'я займають близько 80\% iї території. Лише на південному заході області розташована Закарпатська низовина. Клімат території зумовлений, перш за все, географічним положенням гір, висотою їх над рівнем моря, формою рельєфу. Кліматологи відносять Закарпатську область до атлантично-континентальної кліматичної зони, якій властиві антициклональний режим погоди та клімат помірних широт. Клімат Закарпатської області характеризується достатнім зволоженням, нестійкою весною, не дуже спекотним літом, теплою осінню та м'якою зимою. Температура повітря у Закарпатській області має простий хід із мінімумом у січні та максимумом у липні. Від'ємні середньомісячні температури повітря спостерігаються протягом трьох зимових місяців (грудня, січня, лютого). У цілому за рік вологість повітря над Карпатами підвищена (близька до 80\%). Максимальна вологонасиченість повітря відзначається узимку (80-89\%). Улітку iii значення трохи нижчі (77\%). Найпосушливіше весняне повітря, але і його вологість не зменшується нижче 55\%. Середня річна кількість опадів на території області варіює від 636 до 1600 мм (Pryroda..., 1981).

Кліщів збирали протягом 2012-2014 рр. у садових фітоценозах міст Виноградів, Ужгород, Великий Березний, Чоп, Берегове, Свалява, Мукачеве, Воловець і Перечин (рис.). Для виявлення видового складу кліщів проби брали $з$ плодових культур покинутих садів та присадибних ділянок, а також тих, які зростають уздовж доріг. Обирали культури, не оброблені пестицидами. Матеріалом слугували листки фруктових дерев, кущів і трав нижнього ярусу, а також опале листя цих рослин.

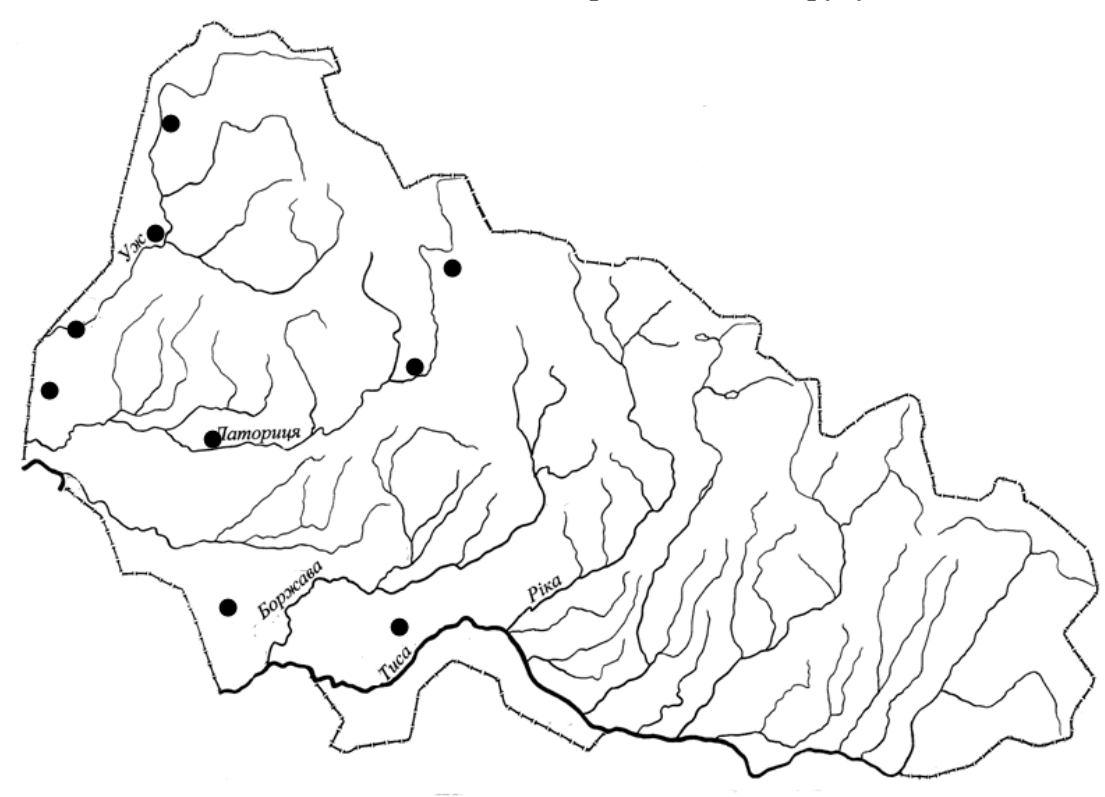

Рис. 1. Карта-схема досліджень комплексів кліщів-фітосеїд на території Закарпатської області

Кліщів відбирали стандартним методом прямого збирання з листків під бінокулярним мікроскопом або струшували їх на папір чорного кольору 3 подальшим перенесенням препарувальною голкою у 70\% розчин спирту. Для визначення кліщів із фіксованого або живого матеріалу виготовляли мікропрепарати 3 використанням рідини Хоєра на предметному скельці (Kuznetsov and Petrov, 1984). Для визначення кліщів використано монографію Л.А. Колодочки (Kolodochka, 1978). Під час дослідження встановлено індекси трапляння Is (Pesenko, $1982)$ та домінування Палія-Ковнацки $\left(\mathrm{D}_{\mathrm{i}}\right)$ (Shitikov et al., 2003), а також описано види рослин, з яких зібрано вид.

Відібрано 311 проб, із яких 287 містили фітосеїдних кліщів. Загалом досліджено 26 видів плодових рослин. 


\section{Результати та їх обговорення}

У кожній конкретній рослинній асоціації кліщіфітосеїди утворюють комплекси, різноманіття яких відображає історію їх формування та може варіювати залежно від віку та особливостей біоценозу (Kolodochka and Omeri, 2011). Важливий показник, який характеризує комплекс кліщів-фітосеїд на рослинах садових фітоценозів Закарпатської області, - статус кожного виду. У резуль-

таті наших досліджень виявлено, що домінує в усіх обстежених пунктах Eu. finlandicus. У лісостеповій зоні Eu. finlandicus також має статус домінантного виду (Omeri, 2013). Нами встановлено індекс трапляння Eu. finlandicus на рослинах садових фітоценозів Закарпатської області.

Ступінь домінування певного виду кліщів визначає його відсоткова участь у дослідженому комплексі. Eu. finlandicus домінує в усіх (100\%) обстежених садових фітоценозах Закарпатської області (табл.).

Таблиия

Індекс трапляння (Is) та домінування (D $\mathrm{D}_{\mathrm{i}}$ Eu. finlandicus на рослинах садових фітоценозів Закарпатської області

\begin{tabular}{|c|c|c|c|c|c|c|c|c|c|}
\hline \multirow{2}{*}{ Досліджуваний показник } & \multicolumn{9}{|c|}{ Населений пункт } \\
\hline & 1 & 2 & 3 & 4 & 5 & 6 & 7 & 8 & 9 \\
\hline Is, $\%$ & 51,4 & 41,8 & 68,3 & 37,5 & 29,1 & 49,2 & 54,7 & 37,6 & 59,3 \\
\hline$D_{\mathrm{i},} \%$ & 19,5 & 25,4 & 14,7 & 37,2 & 17,1 & 23,8 & 11,3 & 44,6 & 20,8 \\
\hline
\end{tabular}

Примітки: 1 - садові фітоценози в м. Ужгород; 2 - садові фітоценози в м. Виноградів; 3 - м. Чоп; 4 - м. Свалява; 5 - м. Мукачеве; 6 - м. Перечин; 7 - м. Великий Березний; 8 - м. Воловець; 9 - Берегове.

У садах околиць м. Виноградів вид трапляється на яблуні садовій (Malus domestica Borkh.), горісі грецькому (Junglans regia L.), шовковиці білій (Morus alba L.), абрикосі звичайному (Armeniaca vulgaris Lam.), вишні звичайній (Cerasus vulgaris Mill.), сливі домашній (Prunus domestica L.), черешні (Cerasus avium (L.) Moench), смородині чорній (Ribes nigrum L.), малині (Rubus idaeus L.), персику (Persica vulgaris Mill.), кизилі справжньому (Cornus mas L.), груші звичайній (Pyrus communis L.), смородині звичайній (Ribes vulgare Lam.).

У садах м. Ужгород Eu. finlandicus знайдено на айві довгастій (Cydonia oblonga Mill.), яблуні садовій, горісі грецькому, шовковиці чорній, абрикосі звичайному, груші звичайній, вишні звичайній, сливі домашній, черешні (Cerasus avium (L.) Moench), смородині чорній, шовковиці білій, обліписі крушиновидній (Нippophae rhamnoides L.). У м. Свалява вид знайдено на аличі звичайній (Prunus divaricata Ledeb.), яблуні садовій, калині звичайній (Viburnum opulus L.), суниці лісовій (Fragaria vesca L.), смородині чорній, груші звичайній, вишні звичайній. У м. Мукачеве Eu. finlandicus зібрано з яблуні садової, горіха грецького, ожини (Rubus caesius L.), агруса відхиленого (Grossularia reclinata (L.) Mill.), сливи домашньої, черешні, смородини чорної, терносливи (Prunus insititia L.), суниць садових (Fragaria ananassa Duch.), аличi, абрикоса звичайного, айви довгастої, вишні звичайної, груші звичайної, обліпихи крушиновидної. У м. Чоп Eu. finlandicus виявлено на аличі, яблуні звичайній, смородині чорній, смородині звичайній, винограді справжньому (Vitis vinifera L.), груші звичайній, горісі грецькому, черешні, суницях садових, вишні звичайній, аронії чорноплідній (Aronia melanocarpa (Michx.) Elliott). У м. Перечин вид трапляється на смородині чорній, горісі грецькому, яблуні садовій, малині, суницях садових, груші звичайній, сливі домашній, винограді справжньому, черешні, абрикосі звичайному, обліписі крушиновидній, ожині. У м. Великий Березний вид знайдено на черешні, яблуні садовій, вишні звичайній, сливі домашній, смородині чорній, калині звичайній, винограді справжньому. У садових фітоценозіх м. Воловець вид трапляється на вишні звичайній, калині звичайній, сливі домашній, аронії чорноплідній, смородині чорній, смородині звичайній, суницях садових, тернос- ливі, ожині. У м. Берегове Eu. finlandicus знайдено на персику, винограді справжньому, яблуні садовій, сливі домашній, агрусі відхиленому, суницях садових, смородині звичайній, обліписі крушиновидній, горісі грецькому.

\section{Висновки}

Eu. finlandicus домінує у садових фітоценозах Закарпатської області. На території досліджень вид значно поширений, не виявляє приуроченості до певного виду рослин. Отримані дані дозволяють вважати Eu. finlandicus фоновим видом у садових фітоценозах Закарпатської області.

\section{Бібліографічні посилання}

Akimov, I.A., Kolodochka, L.A., Zhovnerchuk, O.V., Omeri, I.D., Samojlova, T.P., 2007. Vidovoj sostav i ekolohicheskie osobennosti kleschej nadsemejstva Tetranychoidea (Acariformes, Trombidiformes) i semejstva Phytoseiidae (Parasitiformes, Gamasina), obitayuschih na rosteniyah botanicheskih sadov Kieva (Ukraina) [Species composition and ecological perculiarities of mites of the superfamily Tetranychoidea (Acariformes, Trombidiformes) and family Phytoseiidae (Parasitiformes, Gamasina), inhabiting plants in botanical gardens of Kiev (Ukraine)]. Vestn. Zool. 41(6), 521-534 (in Russian).

Herenchuk, K.I. (ed.), 1981. Pryroda Zakarpatskoyi oblasti [Nature of Transcarpathian region]. Vyshcha Shkola, Lviv (in Ukrainian).

Hrabovskaya, S.L., Kolodochka, L.O., 2014. Vydova rizhnomanitnist klischiv-fitoseid (Parasitiformes, Phytoseiidae) u roslynnih nasadzhennyah mista Vasylkova [The species diversity of Phytoseiidae mites (Parasitiformes) in the plantation of Vasylkiv Town]. Naukoviy Visnik NLTU Ukrai'ny 24(4), 184-190 (in Ukrainian).

Kolodochka, L.A., 1978. Rukovodstvo poopredeleniyu rastenieobitayuschih kleschey-fitoseid [Manual definition of plant living phytoseiid mites]. Naukova Dumka, Kyev (in Russian).

Kolodochka, L.A., Omeri, I.D., 2006. Hischnie kleschi simejstva Phytoseiidae (Acari, Parasitiformes) parkovih soobschestv Centralnoy Lesostepi Ukrainy [Predatory mites of the family Phytoseiidae (Acari, Parasitiformes) in the park 
plant communities of the Central Wood-and-Steppe of Ukraine]. Vestn. Zool. 40(5), 463-467 (in Russian).

Kolodochka, L.A., Omeri, I.D., 2011. Khyshnye kleshchi semejstva Phytoseiidae (Parasitiformes, Mesostigmata) dendrologicheskikh parkov i botanicheskikh sadov Lesostepi Ukrainy [Predatory mites of the family Phytoseiidae (Parasitiformes, Mesostigmata) of dendrological parks and botanic gardens of the Forest-Steppe of Ukraine]. Kyev (in Russian).

Kuznetsov, N.N., Petrov, V.M., 1984. Khishchnie kleshchi Pribaltiki (Parasitiformes: Phytoseiidae, Acariformes: Prostigmata) [Predatory mites of the Baltic States (Parasitiformes: Phytoseiidae, Acariformes: Prostigmata)]. Zinatne, Riha (in Russian).

Omeri, I.D., 2008. Klischi rodyny Phytoseiidae (Parasitiformes, Mesostigmata), yaki meshkayut na roslynah dendroparkiv ta botanichnyh sadiv lisostepu Ukrainy [Plant-inhabiting phytoseiid mites (Parasitiformes, Mesostigmata) in dendrological parks and botanical gardens of the Forest-Steppe of Ukraine]. Thesis for a degree of Candidate of biological sciences by speciality 03.00.08 - zoology. Kiev. (in Ukrainian).

Pesenko, Y.A., 1982. Principy i metody kolichestvennoho analiza i faynisticheskih issledovaniyakh [Principles and methods of quantitative analysis in faunal researches]. Nauka, Moskow (in Russian).

Shitikov, V.K., Rozenbeh, H.S., Zinchenko, T.D., 2003. Kolichestvennaya hidroekolohiya: Metody sistemnoj identifikacii [Quantitative hydrobiology: Methods of system identification]. IEVB RAN, Tolyati (in Russian).

Kolodochka, L.O., 1993. Klishci-fitoseidy (Parasitiformes, Phytoseiidae) - meshkanci roslyn Shidnykh Karpat [Phytoseiid mite (Parasitiformes, Phytoseiidae) - plant residents of the Eastern Carpathians]. Materialy Mizhnar. Konf. «Fauna Skhidnykh Karpat: Suchasnyj stan i okhorona» (Uzhhorod, 13-16.09.1993). Uzhhorod, 197-199 (in Ukrainian).

Omeri, I.D., 2013. Dominiruyuschij vid Euseius finlandicus Oudermans, 1915 (Parasitiformes: Phytoseiidae) akarokompleksov simejstva Phytoseiidae v sadovo-parkovikh fitocenozakh Lesostepi Ukrainy [The dominant species Euseius finlandicus Oudermans, 1915 (Parasitiformes: Phytoseiidae) of acaracomplexes of the family Phytoseiidae in garden's and park's phytocenoses in Forest-Steppe of Ukraine]. Izvestiya Harkovskoho Entomolohicheskoho Obschestva 21(1), 61-66 (in Russian).

Надійшла до редколегії 14.07.2015 